\title{
Stan badań nad historią prawa ubezpieczeń społecznych w okresie II Rzeczypospolitej (1918-1939)
}

DOI: http://dx.doi.org/10.12775/SIT.2015.022

Jeszcze u schyłku lat trzydziestych ubiegłego wieku specjaliści zajmujący się instytucjami prawa ubezpieczeń społecznych mieli wątpliwości co do istnienia odrębnej gałęzi prawa, skupiającej zasadniczo wykształcone i obowiązujące, choć nie tworzące odrębnej formuły procesowej, ustawodawstwo ubezpieczeniowe ${ }^{1}$. Występu-

\footnotetext{
${ }^{1}$ Wskutek odrodzenia suwerennego państwa polskiego ustawodawca zdecydował się na przejęcie prawodawstwa ubezpieczeń społecznych dziedziczonego niejako od zaborców. W ciągu lat dwudziestych XX w. doszło do kodyfikacji ubezpieczenia na wypadek choroby (Dekret Naczelnika Państwa z 1919 r. praktycznie nie wszedł w życie, rozwiązania w nim zawarte powielono w Ustawie z 1920 r.; Dz.U. z 1919 r. Nr 9, poz. 122; Dz.U. z 1920 r. Nr 44, poz. 272), zabezpieczenia na wypadek bezrobocia (Dz.U. z 1924 r. Nr 67, poz. 650) oraz ubezpieczenia emerytalnego pracowników umysłowych (Dz.U z 1927 r. Nr 106, poz. 911). Przez ten czas podtrzymywano partykularyzm prawny Pomorza, Wielkopolski i Górnego Śląska. Dopiero w kolejnym dziesięcioleciu zdecydowano się na scalenie dotąd tak niejednolitego systemu w Ustawie o ubezpieczeniu społecznym z 1933 r. (Dz.U. z 1933 r. Nr 51, poz. 396). Rezultat działań legislacyjnych zdaniem licznych krytyków nie przyniósł faktycznej poprawy sytuacji. Sądownictwo ubezpieczeń społecznych utworzono ustawą z $1939 \mathrm{r}$. (Dz.U. z 1939 r. Nr 71, poz. 476), niestety do momentu wybuchu drugiej wojny światowej sądy nie zostały powołane. Działały one na podstawie przepisów przedwojennych w okresie Polskiej Rzeczypospolitej Ludowej, zastąpione w 1975 r. przez okręgowe sądy pracy i ubezpieczeń społecznych. T. Maciejew-
} 
jące na tym tle w środowisku naukowym podziały zasygnalizował w 1938 r. na łamach „Przeglądu Ubezpieczeń Społecznych” Jerzy Wengierow. Wyróżniano wówczas dwa zasadnicze poglądy w kwestii prawa ubezpieczeń społecznych. Postulowano włączenie go do prawa pracy lub na zasadzie równorzędności względem prawa pracy - ujęcie obydwu w dziedzinę prawa społecznego. Brak prób rozwiązania dylematu Jerzy Wengierow tłumaczył niechęcią badaczy prawa do mierzenia się $z$ aktualnymi problemami teorii prawa: „nauka prawa interesuje się zagadnieniami tradycyjnymi, często drugorzędnego znaczenia, staje zaś przed nowymi kwestiami, jakie nowe prawo przynosi, jak gdyby w osłupieniu, zwłaszcza, że normy prawne, regulujące na nowo życie gospodarczo-społeczne na ogół nie mieszczą się w dotychczasowych systematach naukowych. Toteż istnieją liczne dziedziny prawa leżące dla nauki jakby odłogiem [...]"2.Jerzy Wengierow stwierdzał w konkluzji, że do wykształcenia gałęzi prawa ubezpieczeń społecznych z pewnością przyczyni się utworzenie specjalistycznego pionu sądownictwa ubezpieczeniowego, a co się z tym wiąże - rozwój orzecznictwa. Autor ostatecznie stanął na stanowisku uznania prawa ubezpieczeń społecznych za dział prawa społecznego.

Nie bez związku z kwestią ewentualnego wyodrębnienia prawa ubezpieczeń społecznych pozostawało ujednolicenie nazewnictwa w przepisach prawnych, mających na celu eliminację ryzyka socjalnego (konsekwencji choroby, wypadków przy pracy, utraty pracy, inwalidztwa czy podeszłego wieku). Apel w tej sprawie ukazał się w 1928 r. w „Przeglądzie Ubezpieczeń Społecznych”. Krytyczne uwagi skierowane pod adresem polskiego ustawodawcy wieńczyła refleksja o konieczności wyzyskania momentu scalania norm ubezpieczeń społecznych dla zharmonizowania często sprzecznej ze sobą terminologii. Na marginesie wspomnianego anonimowego napomnienia znalazła się ogólna uwaga na temat stanu literatury

ski, Historia ustroju i prawa sądowego Polski, Warszawa 1999, s. 367, 385; P. Makarzec, Ubezpieczenia społeczne w II Rzeczpospolitej, „Zeszyty Naukowe WSEI. Seria: Administracja” 2012, z. 1, s. 201-207.

2 J.G. Wengierow, Czy istnieje odrębna gałaź wiedzy prawniczej-prawo ubezpieczeń społecznych?, „Przegląd Ubezpieczeń Społecznych” 1938, z. 10, s. 659. 
z zakresu ubezpieczeń społecznych: „przedstawia się ona nad wyraz ubogo. Poza drobnemi broszurkami i nielicznemi komentarzami do poszczególnych ustaw ubezpieczeniowych, brak nam właściwie zupełnie samodzielnych opracowań w tej dziedzinie" ${ }^{3}$. Ta skromna wzmianka stanowi trafne wprowadzenie w zagadnienie badań nad prawem ubezpieczeń społecznych oraz bardziej specjalistycznych, prowadzonych z perspektywy czasowej, badań nad historią prawa ubezpieczeń społecznych.

Nim jednak przejdę do omówienia postępów w badaniach nad dziejami prawa ubezpieczeń w okresie II Rzeczpospolitej, zatrzymam się nad istotą tego pojęcia. Próby jego zdefiniowania podjął się Konstanty Krzeczkowski, stwierdzając w 1936 r., że są nimi „przymusowo tworzone organizacje przezorności społecznej, oparte o wzajemność, dające swym członkom, poszkodowanym przez losowe wypadki, prawo do odszkodowania. Przyjmując to określenie, chcemy stwierdzić, że ubezpieczenia społeczne muszą być tworzone przez państwo, gdyż wtedy tylko swój cel związany z państwem spełniają, że muszą być tworzone przy pomocy przymusu, gdyż chodzi o ich powszechność, że wszelkie ubezpieczenia, w których podstawą zrzeszenia jest dobrowolność nie mają cech wyraźnie ubezpieczeniowych, lecz raczej są to próby zorganizowanej samopomocy"4.

Usiłując ustalić znaczenie terminu ubezpieczenia społeczne, Ignacy Gliksman zwrócił w 1933 r. uwagę na wieloznaczność pojęcia i jego nieostrość, powołując się na licznie przytaczane w jego tekście opinie autorów niemieckich. W swoim wywodzie szczególnie polemizował z przymiotem "przymusowości”, uznawanym przez teoretyków na ogół za cechę konstytutywną omawianych przezeń ubezpieczeń ${ }^{5}$.

Obszerny artykuł na temat ubezpieczeń społecznych pióra Jerzego Czerwińskiego, magistra prawa Uniwersytetu Warszawskiego, ukazał się w drugim tomie encyklopedii prawa z 1930 r. pod re-

${ }^{3}$ Z. Z., Ustalenie terminologii $w$ ubezpieczeniach społecznych, „Przegląd Ubezpieczeń Społecznych” 1928, z. 2, s. 28.

${ }^{4} \mathrm{~K}$. Krzeczkowski, Idee przewodnie ubezpieczeń społecznych, Warszawa 1936, s. 10.

${ }^{5}$ I. Gliksman, Ubezpieczenia społeczne, Warszawa 1933, s. 5-12. 
dakcją Zygmunta Cybichowskiego (1879-1946), wykładowcy prawa międzynarodowego publicznego, profesora Uniwersytetu Lwowskiego i Warszawskiego oraz sędziego Stałego Trybunału Arbitrażowego w Hadze. Autor artykułu stanął na stanowisku wtórnego wobec prawa ochrony pracy charakteru ubezpieczeń społecznych, mających na celu wspomóc finansowo, doświadczających ryzyka socjalnego, ubezpieczonych. Lapidarnie określił ubezpieczenia społeczne jako „kombinację asekuracji prywatnej i społecznego protekcjonalizmu”. Dodał przy tym, że „podstawą ubezpieczeń społecznych są okoliczności, wywierające wpływ na zdolność zarobkowania jednostki”"

Wspomniane opracowanie zawierało niepozorny ustęp o genezie ubezpieczeń społecznych (zaledwie dwa akapity), co w zasadzie okazywało się symptomatyczne dla literatury ubezpieczeniowej okresu międzywojennego. Przechodząc do właściwego problematu artykułu, należy zauważyć, że przed wybuchem drugiej wojny światowej wiele tematów z zakresu dziejów prawa ubezpieczeń społecznych mogło zostać twórczo omówionych, chociażby per analogiam do badań nad historią prawa ubezpieczeń gospodarczych (wzajemnych) ${ }^{7}$. Niestety wśród polskich badaczy nie znaleźli się chętni, aby rozwinąć te wątki.

Ze względu na krótkotrwały okres niepodległości państwa polskiego po zakończeniu wielkiej wojny można odnieść wrażenie, że zainteresowani tematem historii prawa ubezpieczeń społecznych nie odnaleźliby wystarczającego materiału źródłowego do badań,

${ }^{6}$ J. Czerwiński, Ubezpieczenie społeczne, w: Encyklopedia podręczna prawa publicznego (konstytucyjnego, administracyjnego i międzynarodowego, t. II, Warszawa 1930, s. 1047.

7 Chcąc ukazać poziom zaawansowania prac naukowych nad dziejami prawa ubezpieczeń gospodarczych w międzywojniu, dość posłużyć się przykładem monumentalnej (liczącej aż 1467 stron), dwutomowej monografii K. Krzeczkowskiego poświęconej temu zagadnieniu na ziemiach polskich i opatrzonej aneksem, zawierającym szeroki wybór aktów prawa (K. Krzeczkowski, Rozwój ubezpieczeń publicznych $w$ Polsce, t. I, Warszawa 1931; Ibidem, t. II, cz. I-II, Warszawa 1935). Również w podręcznikach akademickich pojawiały się szczegółowe i wyczerpujące zagadnienie rozdziały historyczno-prawne (zob. J. Łazowski, Rozwój historyczny, w: Wstęp do nauki o ubezpieczeniach, Warszawa 1934, s. 25-68). 
a to $z$ tej prostej przyczyny, że polskie regulacje dopiero powstawały. Nic bardziej mylnego! Prima facie, jak skonstatował w początku lat trzydziestych XX wieku Ignacy Gliksman, „ubezpieczenia społeczne są instytucją socjalną nowoczesną i w swej postaci obecnej istnieją koła lat 50"8. Moim zdaniem okres półwiecza umożliwiał spojrzenie $z$ perspektywy chronologicznej, nie wspominając o pozamaterialno-prawnej genezie ustawodawstwa. Mając na uwadze powyższe, istniały $\mathrm{w}$ okresie międzywojennym co najmniej trzy płaszczyzny analiz historyczno-prawnych w obszarze prawa ubezpieczeń społecznych. Primo po 1933 r. pojawiła się płaszczyzna badań nad aktami prawa obowiązującymi przed wejściem w życie tzw. ustawy scaleniowej, która zastąpiła wcześniejsze regulacje. I bynajmniej nie należy ograniczać tej sfery do wglądu w normy prawa materialnego, ale objąć rozważaniami również przepisy proceduralne. Secundo analizy te mogłyby wykraczać daleko poza moment odrodzenia Rzeczypospolitej, bowiem na ziemiach polskich rozwinęło się w ciągu XIX w. ustawodawstwo państw zaborczych, które w znacznej mierze pozostawało aktualne po 1918 r. Obszar badań uległby poszerzeniu, gdyby zająć się nie tylko aktami prawa obowiązującymi w przeszłości, ale również ich propozycjami, historią postulowanych zmian, ewolucją poglądów doktryny na ten temat czy rozwojem myśli prawnej. Tym samym analizy mogłyby objąć okres już od czasów Księstwa Warszawskiego. Tertio zakres dociekań nie musiał zamykać się w późniejszych granicach II Rzeczypospolitej. Można sobie wyobrazić badania historyczno-prawne nad dziejami prawa ubezpieczeń społecznych w Rzeszy Niemieckiej, gdzie w końcu XIX w. wprowadzono pionierskie ustawodawstwo socjalne, czy w Wielkiej Brytanii.

Poniżej zostały omówione prace zawierające uwagi z zakresu historii prawa ubezpieczeń społecznych, które wydano w międzywojennej Polsce. Przegląd objął monografie, podręczniki oraz artykuły $z$ fachowych czasopism.

8 I. Gliksman, Ubezpieczenia społeczne, s. 12. 


\section{Monografie naukowe i podręczniki akademickie}

W okresie międzywojennym wydano przynajmniej pięć prac monograficznych i dwa podręczniki akademickie, w których pojawiły się informacje historyczno-prawne na temat ubezpieczeń społecznych.

Rozpocząć należy od, wyjątkowego na tle pozostałych publikacji, opracowania pióra Konstantego Krzeczkowskiego ${ }^{9}$ pt. Idee przewodnie ubezpieczeń społecznych, wydanego w 1935 r. w Warszawie nakładem Instytutu Spraw Społecznych. Unikalność książki polegała na całościowym ujęciu historycznego rozwoju myśli prawnej, społecznej i politologicznej, odnoszącej się do ubezpieczeń społecznych. Autor wskazał cel i metodę swoich badań, podjął się wyróżnienia historycznych okresów rozwoju myśli, a następnie dokonał ich wszechstronnej charakterystyki nie tylko w oparciu o osiągnięcia polskiej nauki, ale odwołując się także do rozwiązań angielskich, niemieckich, włoskich, francuskich czy holenderskich. Pracy trudno odmówić niewątpliwych walorów naukowych, należy jednak mieć na uwadze socjalistyczne poglądy autora, ujawnione

${ }^{9}$ K. Krzeczkowski urodził się w 1879 r. w Żyrardowie (Wacław Szubert wskazał Guzów k. Żyrardowa jako miejsce urodzenia) w rodzinie o tradycjach powstańczych (styczniowa irredenta). Był działaczem politycznym, społecznym i oświatowym, zajmował się teorią polityki społecznej i bibliologią. Od $1898 \mathrm{r}$. związał się ze strukturami Polskiej Partii Socjalistycznej, od 1906 r. przynależał do jej frakcji lewicowej. Współpracownik B. Miklaszewskiego, od 1916 r. (według W. Szuberta od 1917 r.) zaczął wykładać w Wyższej Szkole Handlowej oraz na Wolnej Wszechnicy Polskiej w Warszawie. Współpracował z Instytutem Spraw Społecznych, Głównym Urzędem Statystycznym oraz Instytutem Gospodarstwa Społecznego. Autor koncepcji jednego ryzyka ubezpieczeniowego „na wypadek niezawinionej utraty zarobku”. Zmarł w grudniu 1939 r. w związku $\mathrm{z}$ aresztowaniem przez gestapo za pracę w Komisji Instytutu Gospodarstwa Społecznego, która uchodziła za prokomunistyczną (W. Szubert wskazał, że K. Krzeczkowski został zakładnikiem). H. Balicka-Kozłowska, Krzeczkowski Konstanty Bronisław (1879-1939), w: Polski Słownik Biograficzny, t. XV, red. E. Rostworowski, Wrocław-Warszawa-Kraków 1970, s. 508-510; W. Szubert, Konstanty Krzeczkowski (1879-1939), „Studia i Materiały z Historii Ubezpieczeń Społecznych w Polsce” 1994, z. 10, s. 105-108. 
w jego diagnozach: „Przyszłość ubezpieczeń społecznych, pomimo ciemnego obrazu w chwili obecnej, posiada jasne barwy i wyraźne kontury. [...] Ubezpieczenia bynajmniej nie osiągnęły kresu w swej strukturze, celach i formach. [...] Wkraczamy w nową fazę rozwojową, fazę nowej utopijności. [...] Gospodarka planowana jest metodycznie najbardziej typowym objawem utopijnego rozumowania. [...] Jutro kapitalizmu - okres planowej gospodarki społecznej - będzie okresem, który możemy nazwać już dzisiaj pozytywnym"10. Praca zawierała streszczenie w języku angielskim.

Alfred Krieger (Krygier) ${ }^{11}$, autor kolejnej cennej pracy monograficznej z zakresu historii prawa ubezpieczeń społecznych, podobnie jak Konstanty Krzeczkowski, związany był z Instytutem Spraw Gospodarczych, który w 1932 r. zdecydował się na publikację jego opracowania pt. Ubezpieczenie na wypadek choroby $w$ Polsce. Lata 1917-1918 (czasy okupacji niemieckiej)12. Przede wszystkim w pracy zostały omówione projekty urzędowe ustaw dotyczących ubezpieczeń chorobowych z 1917 i 1918 r., a także projekty samorządowe w tym zakresie (uchwały rady warszawskiej i samorządu łódzkiego). Przedstawiono również starania organizacji społecznych

${ }^{10}$ K. Krzeczkowski, Idee przewodnie, s. 180, 183.

11 A. Krieger wywodził się z krakowskiej rodziny mieszczańsko-inteligenckiej. Urodził się w 1887 r., w 1911 r. obronił doktorat z prawa na Uniwersytecie Jagiellońskim. Od 1906 r. związany był z organizacjami socjalistycznymi, decydując się po pięciu latach na oficjalne wstąpienie do Polskiej Partii Socjalno-Demokratycznej, później działał w Polskiej Partii Socjalistycznej. W latach 1925-1930 pełnił funkcję zastępcy dyrektora Ogólnopaństwowego Związku Kas Chorych, zaś pomiędzy 1926 i 1930 r. był redaktorem naczelnym „PUS-u”. Po zakończeniu drugiej wojny światowej został wybrany na posła do Sejmu Ustawodawczego początkowo z ramienia Polskiej Partii Socjalistycznej, następnie Polskiej Zjednoczonej Partii Robotniczej. Postawę Kriegera trafnie opisuje cytat z „Polskiego Słownika Biograficznego”: „W pierwszych wystąpieniach [sejmowych - przyp. M.J.M.] Kriegera widać było jeszcze pewien wpływ partii, z której wyszedł. [...] Elementy te jednak szybko zanikły”. Zmarł w 1956 r. i został pochowany w Warszawie. J. Kaczanowska, Krygier Alfred (1887-1956), w: Polski Stownik Biograficzny, t. XV, s. 458-459; W. Szubert, Alfred Krygier (1887-1956), „Studia i Materiały z Historii Ubezpieczeń Społecznych w Polsce” 1991, z. 8, s. 107-111.

12 A. Krieger, Ubezpieczenie na wypadek choroby $w$ Polsce. Lata 1917-1918 (czasy okupacji niemieckiej), Warszawa 1932. 
o wprowadzenie ubezpieczenia chorobowego. Autor nie zapomniał o stosunku różnych grup wobec zagadnienia ubezpieczenia chorobowego. Zarysował stanowiska dominujące w łonie środowiska lekarskiego, reakcje opinii publicznej oraz postawy okupantów. Monografię wzbogacono o sześć załączników, które zawierały m.in. teksty przytoczonych projektów ustaw. Do pracy dołączono streszczenie w języku francuskim. Na marginesie warto wspomnieć, że główny problem poruszony $\mathrm{w}$ monografii stanowił już przedmiot analizy ze strony autora. W 1930 r., a więc dwa lata przed jej publikacją, ukazał się na łamach „Przeglądu Ubezpieczeń Społecznych” artykuł pt. Prace nad ubezpieczeniem na wypadek choroby $w$ okresie okupa$\mathrm{cji}^{13}$. Jego osią był projekt ubezpieczeń społecznych z 1917 r. przygotowany przez Komisję ds. Kas Chorych w Departamencie Pracy Tymczasowej Rady Stanu. Alfred Krieger porównywał projekt do ówczesnego ustawodawstwa chorobowego obowiązującego w Imperium Rosyjskim, II Rzeszy Niemieckiej i Monarchii Austro-Węgierskiej.

Kolejną godną odnotowania pracą monograficzną, w której znalazł się rozdział historyczno-prawny, była publikacja Władysława Fronsberga Babela pt. Ubezpieczenie na wypadek braku pracy $w$ Wielkiej Brytanii ${ }^{14}$, wydana w 1935 r. nakładem Towarzystwa Naukowego we Lwowie. Wyjątkowość opracowania polegała na ujęciu tematu, który został przedstawiony dogmatycznie, a nie komparatystycznie, po wtóre odnosił się do obcych regulacji w perspektywie historycznej. Zajmujący blisko jedną piątą pracy rozdział Rozwój ustawodawstwa o ubezpieczeniu na wypadek braku pracy (s. 2-49) obejmował omówienie poszczególnych aktów prawnych angielskiego ustawodawstwa w przekroju dziejowym aż do czasów współczesnych.

W jubileuszowej publikacji Ministerstwa Opieki Społecznej pt. Polityka społeczna państwa polskiego 1918-1935 znalazł się rozdział, w którym zawarto wiadomości o obowiązującym ówcześnie prawie ubezpieczeń społecznych oraz historii ich kodyfikacji na

13 Idem, Prace nad ubezpieczeniem na wypadek choroby $w$ okresie okupacji, „Przegląd Ubezpieczeń Społecznych” 1930, z. 5, s. 99-106.

14 W. Fronsberg Babel, Ubezpieczenie na wypadek braku pracy $w$ Wielkiej Brytanii, Lwów 1935. 
ziemiach polskich ${ }^{15}$. Zgodnie ze wskazaniem w tytule treść objęła dopiero okres od chwili odrodzenia Rzeczypospolitej, za to szczegółowo omówiono partykularyzmy, m.in. występujące na Górnym Śląsku.

Kończąc omawianie uwag historyczno-prawnych zawartych w pracach monograficznych, należy przypomnieć o monumentalnej (liczącej ponad pięćset stron) publikacji Natalii Gąsiorowskiej na temat górnictwa i hutnictwa w Królestwie Kongresowym ${ }^{16}$, w którym znalazły się informacje o emeryturach górniczych, stowarzyszeniach i funduszach emerytalnych, kasach górniczych i brackich (tzw. Knappschaftskassen), zgromadzeniach górniczych oraz o ubezpieczeniach i odszkodowaniach chorobowych górników.

Wiadomości $z$ dziejów ubezpieczeń społecznych nie zabrakło również w pierwszym polskim podręczniku akademickim $z$ tej dziedziny ${ }^{17}$. W zasadzie stanowił on streszczenie wykładów głoszonych przez Ignacego Biskupskiego, wykładowcę Uniwersytetu Poznańskiego. Rozważania historyczno-prawne zostały zawarte w drugim rozdziale podręcznika pt. Historia rozwoju ubezpieczeń (s. 13-47). Za recenzję treści tego fragmentu niech posłuży krytyka Jana Łazowskiego ${ }^{18}$ ogłoszona na łamach „Ekonomisty” w 1928 r.: „Zwłaszcza jej [książki Biskupskiego] część ogólna ujawnia szereg braków: [...] część historyczna pomija szereg nadzwyczaj interesujących pier-

15 Część VI. Ubezpieczenia społeczne, w: Polityka społeczna państwa polskiego 1918-1935, red. M. Bornstein-Łychowska, Warszawa 1935, s. 221-288.

${ }^{16}$ N. Gąsiorowska, Górnictwo i hutnictwo w Królestwie Polskiem 1815-1830, Warszawa 1922.

17 I. Biskupski, O ubezpieczeniach, Poznań 1925.

18 J. Łazowski urodził się w 1889 r. w Warszawie, jego ojciec był inżynierem. W 1916 r. uzyskał doktorat z prawa, natomiast jeszcze w czasie studiów na Uniwersytecie Jagiellońskim związał się z lewicową frakcją Polskiej Partii Socjalistycznej. W 1918 r. działał w Komunistycznej Partii Robotniczej Polski. W latach 1923-1926 pełnił funkcję zastępcy naczelnika wydziału w Departamencie Ubezpieczeń Społecznych w Ministerstwie Pracy i Ubezpieczeń Społecznych. Przygotował pierwszy projekt ustawy emerytalnej o ubezpieczeniu pracowników fizycznych. Wykładowca w Szkole Nauk Politycznych (od 1921 r.) oraz w Wyższej Szkole Handlowej w Warszawie (od 1922 r.). W 1936 r. ponownie przystąpił do Polskiej Partii Socjalistycznej. Najprawdopodobniej zmarł w $1941 \mathrm{r}$. obozie oświęcimskim, gdzie spędził ponad rok. S. Wrzosek, Łazowski Jan Stanisław (1889-1941), w: Polski Stownik Biograficzny, red. E. Rostworowski, Wrocław-Warszawa-Kraków 1973, t. XVIII, s. 298-300. 
wotnych form umowy ubezpieczeniowej, a historia polskiej asekuracji jest raczej historią osób, niż historią rozwoju instytucyj na tle ogólnych stosunków gospodarczych. [...] Książka Biskupskiego jest pierwszą próbą w Polsce dania polskiemu czytelnikowi podręcznika nauki o ubezpieczeniach i dlatego wydanie jej, pomimo braków wykładu, stanowi poważną zasługę autora"19.

Również Ignacy Gliksman, przygotowując podręcznik z zakresu ubezpieczeń społecznych ${ }^{20}$, nie zapomniał o włączeniu uwag historyczno-prawnych, które rozsiane są w różnych miejscach publikacji. Brak natomiast w dziele wyodrębnionego rozdziału zawierającego treści historyczno-prawne (choć pojawiła się w rozważaniach wstępnych Geneza socjologiczna ubezpieczeń społecznych). Problem ubezpieczeń został potraktowany przez autora wszechstronnie, bowiem zarówno z punktu widzenia socjologii, politologii, jak i prawa.

\section{Czasopisma naukowe}

Prócz omówionego uprzednio artykułu Alfreda Kriegera w związku z jego zbliżoną tematycznie publikacją monograficzną, w okresie międzywojennym pojawiło się co najmniej dziewięć artykułów historycznych w czasopismach specjalizujących się w prawie ubezpieczeń społecznych czy ekonomii. Największą ich liczbę ogłoszono drukiem w „Przeglądzie Ubezpieczeń Społecznych”, sporadycznie pojawiały się w „Ekonomiście”, zaś incydentalnie w „Ruchu Prawniczym, Ekonomicznym i Socjologicznym”, „Pracy i Opiece Społecznej”, „Kwartalniku Historycznym” czy „Przeglądzie Górniczo-Hutniczym”. Na uwagę zasługuje zwłaszcza „Przegląd Ubezpieczeń Społecznych”, organ Ogólnopaństwowego Związku Kas Chorych w Polsce, miesięcznik wydawany od 1926 r. Redaktorem naczelnym „Przeglądu” był w latach 1926-1929 wspomniany Alfred Krieger ${ }^{21}$. Prócz artykułów historyczno-prawnych, w dziale Kroniki zagranicznej poja-

19 J. Łazowski, Wiedza ubezpieczeniowa $w$ Polsce, „Ekonomista” 1928, t. II, s. 54 .

${ }^{20}$ I. Gliksman, Ubezpieczenia społeczne, Warszawa 1933.

${ }^{21}$ J. Łazowski, Wiedza ubezpieczeniowa, s. 58. 
wiały się uwagi o takim charakterze na marginesie analiz reform prawa ubezpieczeń społecznych w różnych krajach świata, często tak egzotycznych jak państwa Ameryki Łacińskiej ${ }^{22}$.

Problematyka poruszana w artykułach historyczno-prawnych publikowanych $\mathrm{w}$ okresie międzywojennym zasadniczo mieści się w trzech płaszczyznach rozważań nad: nieobowiązującym polskim ustawodawstwem ubezpieczeń społecznych, rozwojem ubezpieczeń górników i hutników na Górnym Śląsku, w Zagłębiu Dąbrowskim i Krakowskim oraz projektami aktów prawnych $z$ epoki rozbiorowej. Wśród rozmaitości znalazły się studia z zakresu dziejów organizacji ubezpieczeniowych, ściślej rzecz ujmując, przeanalizowano genezę i rozwój kompetencji Izby Ubezpieczeń Społecznych ${ }^{23}$.

Tematykę nieaktualnego rodzimego ustawodawstwa ubezpieczeń społecznych poruszyli w swoich artykułach Ignacy Gliksman ${ }^{24}$ i Rafał Buber ${ }^{25}$. Pierwszy $z$ autorów w 1936 r. przedstawił zmiany w polskim prawie ubezpieczeń społecznym od czasu odrodzenia państwa polskiego, zaś drugi porównał założenia Dekretu Naczelnika Państwa o obowiązkowym ubezpieczeniu na wypadek choroby ${ }^{26} \mathrm{z}$ przepisami ustawy regulującymi tę materię prawną z 1920 r. ${ }^{27}$ Częściowo do problematyki nawiązywał artykuł Jana Łazowskiego opublikowany w „Pracy i Opiece Społecznej” w 1927 r. ${ }^{28}$, którego treść stanowiła uzasadnienie projektu Ustawy o obowiązkowym ubezpieczeniu chorobowym robotników na wypadek niezdolności do pracy i ich rodzin na wypadek śmierci ubezpieczonego. Autor dokonał analizy historii procesów tzw. scalenia przepisów w Polsce i wybranych

22 Rozwój obowiąkowego ubezpieczenia od wypadków w Costarica, „Przegląd Ubezpieczeń Społecznych” 1934, z. 5, s. 311; Reforma ubezpieczeń społecznych w Urugwaju, „Przegląd Ubezpieczeń Społecznych” 1935, z. 1, s. 60-61.

${ }^{23}$ S. Balcerski, Geneza i zakres działania Izby Ubezpieczeń Społecznych, „Przegląd Ubezpieczeń Społecznych” 1934, z. 2, s. 80-83.

${ }^{24}$ I. Gliksman, Ewolucja ubezpieczeń w Polsce od 1919 do 1935 r., „Ruch Prawniczy, Ekonomiczny i Socjologiczny” 1936, z. 3, s. 234-242.

${ }^{25}$ R. Buber, Dekret z 11 I 1919 a Ustawa z 19 V 1920, „Przegląd Ubezpieczeń Społecznych" 1930, z. 5, s. 106-108.

${ }^{26}$ Dz.U. z 1919 r. Nr 9, poz. 122.

27 Dz.U. z 1920 r. Nr 44, poz. 272.

${ }^{28}$ J. Łazowski, Zagadnienie scalenia ubezpieczeń społecznych a polskie projekty ustawodawcze, „Praca i Opieka Społeczna” 1927, z. 1, s. 41-50. 
państwach europejskich, a także omówił rozwój myśli prawnej odnoszącej się do kwestii ujednolicenia ryzyka socjalnego w prawie.

Partykularyzm ubezpieczeń społecznych wśród górników i hutników utrzymujący się również w czasach II Rzeczypospolitej budził szczególne zainteresowanie wśród historyków prawa. Zwłaszcza warstwa organizacyjna ubezpieczeń społecznych okazywała się wdzięcznym przedmiotem badawczym. W okresie międzywojennym dokonano analizy rosyjskiego prawodawstwa ubezpieczeniowego od czasów utworzenia Królestwa Kongresowego do czasów współczesnych i omówiono praktykę funkcjonowania tzw. kas pomocy na terenie Zagłębia Dąbrowskiego ${ }^{29}$. Scharakteryzowano także podstawy prawne, kompetencje i sposób funkcjonowania Spółki Brackiej w Tarnowskich Górach ${ }^{30}$. Natomiast w artykule wspomnianej Natalii Gąsiorowskiej pojawiło się całościowe ujęcie stanu prawodawstwa państwowego dotyczącego kas brackich, ich organizacji w państwach niemieckich, Księstwie Warszawskim, a następnie Królestwie Kongresowym. Autorka uwzględniła również ustawodawstwo fabryczne, instrukcje władz górniczych, a - co szczególnie interesujące - dołączyła tekst instrukcji, której egzemplarz przesłano w 1828 r. niejakiemu Wilhelmowi Beckerowi, kierownikowi poszukiwań soli w Szczerbakowie ${ }^{31}$, celem zaprowadzenia kas górniczych przy odkrywce soli ${ }^{32}$.

${ }^{29}$ T. Pindelski, Kasy pomocy dla robotników $w$ zakładach górniczych $i$ hutniczych w Zagłębiu Dąbrowskim, „Przegląd Górniczo-Hutniczy” 1924, nr 7, s. 446-448. Artykuł stanowił fragment większej całości, ostatecznie nie wydrukowano pozostałych części, choć pojawiła się zapowiedź kontynuacji.

${ }^{30}$ Jonda, Historia i zakres działania Spółki Brackiej w Tarnowskich Górach, „Przegląd Ubezpieczeń Społecznych” 1930, z. 11, s. 261-264.

31 Szczerbaków jest niewielką wsią położoną obecnie w województwie świętokrzyskim nieopodal Wiślicy, zaś w 1828 r. znajdował się w obrębie województwa krakowskiego. Pomiędzy 1820 a 1840 r. poszukiwano w Szczerbakowie z powodzeniem pokładów soli. Wnioski z przeprowadzonych prac odkrywkowych stanowiły materiał do pracy W. Beckera pt. „Ueber die Flötzgebirge im südlichen Polen, besonders in Hinsicht auf Steinsalz und Soole“, wydanej w 1830 r. we Freyburgu. B. Chlebowski, Szczerbaków, w: Słownik geograficzny Królestwa Polskiego i innych krajów słowiańskich, t. XI, red. B. Chlebowski, W. Walewski, F. Sulimierski, Warszawa 1890, s. 848.

${ }^{32}$ N. Gąsiorowska, Organizacja Kas Brackich górniczych w Królestwie Polskiem (1815-1830), „Kwartalnik Historyczny” 1928, z. 2, s. 291-305. 
Do popularyzacji wiedzy z dziejów ubezpieczeń społecznych bez wątpienia przyczynił się w znacznym stopniu Konstanty Krzeczkowski, skupiający swe wysiłki badawcze na dotąd nieznanych szerzej projektach aktów prawnych. Przybliżył on czytelnikom „Ekonomisty” dwie inicjatywy prawne, które nie doczekały się przyjęcia i wejścia w życie. Pierwszą z nich był projekt regulacji kwestii ubezpieczeń społecznych, złożony 1 czerwca 1808 r. Księciu Warszawskiemu w Dreźnie przez Rosenfelda de Thorn ${ }^{33}$. W aneksie autor artykułu przytoczył pełną treść projektu. W 1930 r. Konstanty Krzeczkowski zaprezentował rezultaty badań nad projektem $z$ lat 1833-1834 przygotowanym przez Antoniego Baumana ${ }^{34}$, poborcę podatkowego z Augustowa, a następnie zwróconego mu przez kancelarię Iwana Paskiewicza, namiestnika Królestwa Polskiego ${ }^{35}$.

\section{Podsumowanie}

„Historia ubezpieczeń społecznych nie została jeszcze napisana. W dotychczasowych próbach historii ubezpieczeń [...] brano jednostronnie pod uwagę jedynie rozwój samych instytucyj [...]. W ten sposób przedstawiana historia była niewielkim odcinkiem przeszłości, obejmowała historię półwiekowych wysiłków organizowania ubezpieczeń, była jedynie epizodem bez początków i następstw. Nowej barwy i nowego życia nabierze historia ubezpieczeń dopiero wtedy, gdy dzieje tych urządzeń obejmą również cały okres projektów i pomysłów ubezpieczeniowych poprzedzających ich realizację. Jest to wielkie zadanie, które stanęło przed badaczami i którego dotąd

${ }^{33}$ K. Krzeczkowski, Projekt ubezpieczeń społecznych z czasów Księstwa Warszawskiego, „Ekonomista” 1929, t. II, s. 134-144.

${ }^{34}$ Propozycja ta nosiła nazwę: „Pomysł do projektu utworzenia Towarzystwa Ogólnego zabezpieczenia osób tak cywilnych jako i wojskowych, składającego się z trzech oddziałów, to jest zapomogi, emerytalnego i konserwacyjnego, a to dla zupełnego zapobieżenia żebractwu i włóczęgostwu, w klasie niższej ludu praktykowanemu".

${ }^{35}$ Idem, Projekt ubezpieczeń społecznych z epoki paskiewiczowskiej, „Ekonomista” 1930, t. II, s. 134-140. 
nie wykonano"36. Taką diagnozę na temat rozwoju badań historyczno-prawnych w przedmiocie ubezpieczeń społecznych postawił Konstanty Krzeczkowski w 1936 r. przy okazji wydania monografii z zakresu doktryn polityczno-prawnych.

Trudno odmówić jej słuszności wziąwszy pod uwagę stan nie tylko literatury historyczno-prawnej, ale również zainteresowania dogmatyczną i współczesną stroną instytucji prawa ubezpieczeń społecznych. Jan Łazowski rozwiał wszelkie wątpliwości w tej materii, punktując w 1928 r. osiągnięcia rodzimej nauki ubezpieczeń społecznych: „[...] polska wiedza ubezpieczeniowa jest jeszcze bardzo ubogą. Brak podstawowych dzieł, czasopism naukowych, nauczanie jest w stadium powstawania. Uzdrowienie wewnętrznych stosunków polskiej asekuracji i widoki rozbudowy ubezpieczeń społecznych stwarzają podstawy dalszego rozwoju polskiej wiedzy ubezpieczeniowej”37. Również polskie bibliografie prawnicze z okresu II Rzeczpospolitej nie wyróżniały działu „prawa ubezpieczeń społecznych”, a tym bardziej jego historii ${ }^{38}$.

Summa summarum, nie lekceważąc dorobku badaczy podejmujących się analizy zagadnień $z$ dziejów prawa ubezpieczeń społecznych, trudno uznać ich pionierskie dokonania za torujące drogę nowej specjalizacji w ramach historii prawa. Osiągnięć tych nie sposób porównywać $z$ wydanymi ówcześnie pomnikowymi dziełami z zakresu ubezpieczeń gospodarczych, które stały się tematem twórczo rozwijanym przez naukowców okresu powojennego.

Autorzy publikujący w latach 1918-1939 zajmowali się problematyką dziejów prawa ubezpieczeń społecznych jedynie epizodycznie, na marginesie swoich szerszych analiz z dziedziny socjologii, politologii czy jurysprudencji. Nie zarysowano programu badań, co oznaczało, że dobór tematów opracowań miał charakter przypadkowy.

${ }^{36}$ Idem, Idee przewodnie, s. 15.

37 J. Łazowski, Wiedza ubezpieczeniowa, s. 66.

38 Zob. P. Dąbkowski, Powszechna kronika historyczno-prawna, „Pamiętnik historyczno-prawny” 1927, t. 5, z. 1; K. Koranyi, Bibliografia historyczno-prawna za lata 1926-1936, t. 1, Lwów 1938; Ibidem, t. 2, Lwów 1939; K. i J. Koranyi, Bibliografia historyczno-prawna za lata 1937-1947, t. 1, Toruń 1953; Ibidem, t. 2, Toruń 1959. 
Niełatwo wskazać luminarza czy koryfeusza tej efemerycznej specjalizacji. Warto jednakże podkreślić zasługi Konstantego Krzeczkowskiego świadomego odrębności przedmiotu prowadzonych przezeń badań. W pełni rozumiejąc znaczenie swojej pracy, postanowił ją nieco usystematyzować i zajął się opracowywaniem historycznych projektów aktów prawnych $z$ dziedziny prawa ubezpieczeń społecznych. W rezultacie napisał dwa skromne artykuły, jednakże bardzo merytoryczne i spełniające kryteria naukowej rzetelności.

En passant dostrzegalne jest podobieństwo orientacji politycznej pisarzy podejmujących omawiany problem. Mianowicie zarówno Konstanty Krzeczkowski, jak i Alfred Krieger czy Jan Łazowski od wczesnej młodości związani byli z ugrupowaniami komunistycznymi czy socjaldemokracją. Ich zapatrywania przełożyły się na późniejsze zainteresowania naukowe oraz szczególnie oddanie sprawom społecznym.

Oceniając rozwój badań nad historią prawa ubezpieczeń społecznych $\mathrm{w}$ okresie międzywojennym w Polsce, na podstawie analizy zebranego materiału należy stwierdzić, że, pomimo możliwości opracowania dziejów prawa obowiązującego przed odrodzeniem państwa polskiego (zwłaszcza na terenie zaboru pruskiego) czy rozwijania wątków historyczno-prawnych w pracach na temat ustawodawstwa państw trzecich, omawiana specjalność pozostała prawniczą terra incognita.

\section{STRESZCZENIE}

Stan badań nad historią prawa ubezpieczeń społecznych w okresie II Rzeczypospolitej (1918-1939)

W okresie międzywojennym nie rozwinęła się w Polsce naukowa literatura z zakresu prawa ubezpieczeń społecznych, tym bardziej w ujęciu historyczno-prawnym. Pomimo wyróżnienia licznych wątków możliwych do opracowania przed wybuchem drugiej wojny światowej, polscy badacze prawa na ogół nie byli zainteresowani tak wąską specjalizacją. Wyjątek stanowił Konstanty Krzeczkowski, który uświadamiał sobie odrębność studiów prawniczych nad dziejami ubezpieczeń społecznych i realizował w tym zakresie skromny projekt badawczy. Zrozumienie kwestii przejawiali 
również Alfred Krieger oraz Jan Łazowski. Tematyka historii prawa ubezpieczeń społecznych podejmowana była incydentalnie. Dorobek polskich autorów w tym zakresie należy ocenić jako nieznaczący, zaś zainteresowanie przedmiotem - powierzchowne.

Słowa kluczowe: historia badań na prawem ubezpieczeń społecznych; II Rzeczpospolita (1918-1939); Alfred Krieger (1887-1956); Konstanty Krzeczkowski (1879-1939); Jan Łazowski (1889-1941)

\section{SUMMARY}

The state of research on the history of social insurance law with in the Second Polish Republic (1918-1939)

The scientific literature on the social insurance law, especially from historical perspective did not develop in the interwar Poland. Despite the numerous identified issues that seemed to be successfully formulated before the outbreak of the Second World War, Polish researchers generally were not interested in such a narrow specialization. The exception was Konstanty Krzeczkowski, who was aware of the separateness of legal studies on the social insurance history and perform a meagre research project in this regard. Alfred Krieger and Jan Łazowski also evinced understanding of the abovementioned problems. The subject matter of the history of social insurance law was incidentally taken up. The achievements of Polish authors in this field should be assessed as insignificant, and their interest in the subject - superficial.

Keywords: the history of research on the social insurance law; the Second Polish Republic (1918-1939);Alfred Krieger (1887-1956); Konstanty Krzeczkowski (1879-1939); Jan Łazowski (1889-1941)

\section{BIBLIOGRAFIA}

Balcerski S., Geneza i zakres działania Izby Ubezpieczeń Społecznych, „Przegląd Ubezpieczeń Społecznych” 1934, z. 2.

Balicka-Kozłowska H., Krzeczkowski Konstanty Bronisław (1879-1939), w: Polski Stownik Biograficzny, t. XV, red. E. Rostworowski, Wrocław-Warszawa-Kraków 1970. 
Becker W., Ueber die Flötzgebirge im südlichen Polen, besonders in Hinsicht auf Steinsalz und Soole, Freyburg 1830.

Biskupski I., O ubezpieczeniach, Poznań 1925.

Buber R., Dekret z 11 I 1919 a Ustawa z 19 V 1920, „Przegląd Ubezpieczeń Społecznych” 1930, z. 5.

Chlebowski B., Szczerbaków, w: Stownik geograficzny Królestwa Polskiego $i$ innych krajów słowiańskich, t. XI, red. B. Chlebowski, W. Walewski, F. Sulimierski, Warszawa 1890.

Czerwiński J., Ubezpieczenie społeczne, w: Encyklopedia podręczna prawa publicznego (konstytucyjnego, administracyjnego i międzynarodowego, t. II, Warszawa 1930.

Dąbkowski P., Powszechna kronika historyczno-prawna, „Pamiętnik historyczno-prawny" 1927, t. 5, z. 1.

Fronsberg Babel W., Ubezpieczenie na wypadek braku pracy $w$ Wielkiej Brytanii, Lwów 1935.

Gąsiorowska N., Górnictwo i hutnictwo w Królestwie Polskiem 1815-1830, Warszawa 1922.

Gąsiorowska N., Organizacja Kas Brackich górniczych w Królestwie Polskiem (1815-1830), „Kwartalnik Historyczny” 1928, z. 2.

Gliksman I., Ewolucja ubezpieczeń w Polsce od 1919 do 1935 r., „Ruch Prawniczy, Ekonomiczny i Socjologiczny” 1936, z. 3.

Gliksman I., Ubezpieczenia społeczne, Warszawa 1933.

Jonda, Historia i zakres działania Spółki Brackiej w Tarnowskich Górach, „Przegląd Ubezpieczeń Społecznych” 1930, z. 11.

Kaczanowska J., Krygier Alfred (1887-1956), w: Polski Stownik Biograficzny, t. XV.

Koranyi K., Bibliografia historyczno-prawna za lata 1926-1936, t. 1, Lwów 1938.

Koranyi K., Bibliografia historyczno-prawna za lata 1926-1936, t. 2, Lwów 1939.

Koranyi K. i J., Bibliografia historyczno-prawna za lata 1937-1947, t. 1, Toruń 1953.

Koranyi K. i J., Bibliografia historyczno-prawna za lata 1937-1947, t. 2, Toruń 1959.

Krieger A., Prace nad ubezpieczeniem na wypadek choroby $w$ okresie okupacji, „Przegląd Ubezpieczeń Społecznych” 1930, z. 5.

Krieger A., Ubezpieczenie na wypadek choroby w Polsce. Lata 1917-1918 (czasy okupacji niemieckiej), Warszawa 1932.

Krzeczkowski K., Idee przewodnie ubezpieczeń społecznych, Warszawa 1936.

Krzeczkowski K., Projekt ubezpieczeń społecznych z czasów Księstwa Warszawskiego, „Ekonomista” 1929, t. II. 
Krzeczkowski K., Projekt ubezpieczeń społecznych z epoki paskiewiczowskiej, „Ekonomista” 1930, t. II.

Krzeczkowski K., Rozwój ubezpieczeń publicznych w Polsce, t. I, Warszawa 1931.

Krzeczkowski K., Rozwój ubezpieczeń publicznych w Polsce, t. II, cz. I-II, Warszawa 1935.

Łazowski J., Rozwój historyczny, w: Wstęp do nauki o ubezpieczeniach, Warszawa 1934.

Łazowski J., Wiedza ubezpieczeniowa $w$ Polsce, „Ekonomista” 1928, t. II. Łazowski J., Zagadnienie scalenia ubezpieczeń społecznych a polskie projekty ustawodawcze, „Praca i Opieka Społeczna” 1927, z. 1.

Maciejewski T., Historia ustroju i prawa sądowego Polski, Warszawa 1999. Makarzec P., Ubezpieczenia społeczne w II Rzeczpospolitej, „Zeszyty Naukowe WSEI. Seria: Administracja” 2012, z. 1.

Pindelski T., Kasy pomocy dla robotników $w$ zakładach górniczych $i$ hutniczych w Zagtębiu Dąbrowskim, „Przegląd Górniczo-Hutniczy” 1924, nr 7.

Polityka społeczna państwa polskiego 1918-1935, red. M. Bornstein-Łychowska, Warszawa 1935.

Reforma ubezpieczeń społecznych w Urugwaju, „Przegląd Ubezpieczeń Społecznych” 1935, z. 1.

Rozwój obowiązkowego ubezpieczenia od wypadków w Costarica, „Przegląd Ubezpieczeń Społecznych” 1934, z. 5.

Szubert W., Alfred Krygier (1887-1956), „Studia i Materiały z Historii Ubezpieczeń Społecznych w Polsce” 1991, z. 8.

Szubert W., Konstanty Krzeczkowski (1879-1939), „Studia i Materiały z Historii Ubezpieczeń Społecznych w Polsce” 1994, z. 10.

Wengierow J.G., Czy istnieje odrębna gałaź wiedzy prawniczej - prawo ubezpieczeń społecznych?, „Przegląd Ubezpieczeń Społecznych”1938, z. 10.

Wrzosek S., Łazowski Jan Stanisław (1889-1941), w: Polski Słownik Biograficzny, red. E. Rostworowski, Wrocław-Warszawa-Kraków 1973, t. XVIII.

Z. Z., Ustalenie terminologii $w$ ubezpieczeniach społecznych, „Przegląd Ubezpieczeń Społecznych” 1928, z. 2. 